\title{
New species and first record of Coeliaria Mulsant, 1850 (Coleoptera: Coccinellidae) from French Guiana
}

\author{
Julissa Churata Salcedo ${ }^{1,2}$ \& Lúcia Massutti de Almeida ${ }^{1,3}$
}

1 Universidade Federal do Paraná (UFPR), Departamento de Zoologia (DZO0), Laboratório de Sistemática e Bioecologia de Coleoptera (LSBC). Curitiba, PR, Brasil.

${ }^{2}$ ORCID: http://orcid.org/0000-0001-7206-3391. E-mail: julissa.cs@gmail.com

${ }^{3}$ ORCID: http://orcid.org/0000-0003-4277-711X. E-mail: lalmeida@ufpr.br

\begin{abstract}
The genus Coeliaria Mulsant, 1850 of the tribe Chnoodini Mulsant, 1850 is recorded for French Guiana for the first time. One new species, Coeliaria monnei Churata \& Almeida sp. nov. (holotype male deposited in MNHN: Montagne des Chevaux $04^{\circ} 44^{\prime} 56^{\prime \prime} \mathrm{N}, 52^{\circ} 26^{\prime} 28^{\prime \prime} \mathrm{W}, 75 \mathrm{~m}, 26 . \mathrm{IX} .2015$, SEAG col.) is described and illustrated. The key published anteriorly is modified to include this new species. Currently, the genus is recorded for Brazil, Bolivia, Paraguay and French Guiana.
\end{abstract}

Key-Words. Coccinellinae; Chnoodini; Identification key; Taxonomy.

\section{INTRODUCTION}

Coeliaria Mulsant, 1850 is a Neotropical genus of Coccinellidae Latreille, 1807 and is included in the tribe named Chnoodini, created by Mulsant in 1850. This genus was revised based on the external morphology and genitalia of the adults (Churata-Salcedo \& Almeida, 2017) and is distinguished by the following characters: dorsal surface pubescent; antenna 11-segmented; hypomera with rounded fovea; tibia flat and angulated; abdominal postcoxal line incomplete with oblique line. Until now, Coeliaria was represented by four species and none of them featured spot on the elytra: Coeliaria castanea Churata-Salcedo \& Almeida, 2017 and C. luteicornis (Mulsant, 1850) (Brazil), C. erythrogaster Mulsant, 1850 (Brazil and Bolivia), C. bernardinensis (Brèthes, 1925) (Brazil and Paraguay). In this study, we recorded the genus for the first time for French Guiana and describe and illustrate one new species, C. monnei Churata \& Almeida sp. nov.

\section{MATERIAL AND METHODS}

The specimens examined were provided by the "Inventaire Entomologique", conducted in French Guiana by SEAG - Société Entomologique Antilles-Guyane. The mouthparts, antennae, legs, abdomen and genitalia dissected were stored in microvials with glycerin. Photographs were taken using a Leica DMC 2900 Digital Camera attached to Leica M205C stereomicroscope using Leica Application Suite. The terminology used in the descriptions follows Churata-Salcedo \& Almeida (2017). Labels of the type specimens are arranged in sequence from top to bottom, where the data for each label are within double quotes (" "), a slash (/) separates the rows, and information between brackets ([ ]) provides additional details written on the labels.

Depositories: The specimens are deposited in Muséum National d'Histoire Naturelle, Paris, France (MNHN) and Coleção Entomológica Pe. J.S. Moure, Departamento de Zoologia, Universidade Federal do Paraná, Curitiba, Brazil (DZUP).

\section{RESULTS}

\section{Coeliaria monnei Churata \& Almeida sp. nov. (Figures 1A-M)}

Diagnosis: Coeliaria monnei sp. nov. resembles C. erythrogaster by the size and black color of the pronotum, but is distinguished by having one big red spot in each elytron, which not extends at the outer border and by the genitalia pattern.

Description: Length $6.95 \mathrm{~mm}$, width $6.54 \mathrm{~mm}$. Male: Body hemispherical, rounded and convex, with fine, short, thick and white pubescence 
(Figs. 1A, 1E, 1F); integument dark brown (Fig. 1B). Head dark, antennae yellowish red and mouthparts brownish black (Figs. 1B, 1D). Pronotum transverse, narrower than elytra, with anterior margin emarginated, lateral margin straight, rounded anteriorly and posteriorly, posterior margin subsinuous (Fig. 1D), hypomera with deep, rounded fovea (Fig. 1C). Prosternal process with rounded apex, a little strangulated at the middle, without carina. Scutellar shield black. Elytra dark, strongly expanded with one big red spot in each elytron, which extends throughout the elytral disc that does not cover the outer border of them. (Figs. 1A, 1E); epipleurae wide, narrowing towards apex, deeply excavated for reception of femoral apex (Fig. 1B). Meso- and metaventrite brownish. Legs brown or dark brown, with flattened femora and tibiae, with acute angulation on outer margin (Fig. 1B). Abdomen with incomplete post-coxal line, attached to posterior margin of first ventrite, with oblique line (Fig. 1G). Genitalia symmetrical; tegmen with penis guide in ventral view symmetrical, broad at base, expanded after middle and narrowing at apex; parameres slightly wide, with short bristles, $0.3 x$ longer than penis guide (Figs. $1 \mathrm{H}-\mathrm{I}$ ). Penis sclerotized, J-shaped, with rounded apex, penis capsule with highly developed inner arm (Fig. 1J). Female: Length 7.27-7.6 mm, width 6.67-7.2 mm. Similar to male. Coxites $2.5 x$ longer than wide, sub-triangular, apex with long bristles; mammiliform style (Fig. 1L). Spermatheca C-shaped, with acute apex and highly developed ramus (Fig. 1K).

Variation: In some specimens, there is a narrow black band in the elytral suture with a rounded black central spot corresponding to $1 / 6$ of the size of the suture (Fig. 1F).

Etymology: The name of this species is in honour of the dedicated entomologist Dr. Miguel Angel Monné, an enthusiastic researcher of beetles, who celebrated 80 years old last year.

Geographical distribution: Montagne des Chevaux, French Guiana.

Type material: HOLOTYPE: 1 male, with labels: "Guyane Française $/ 04^{\circ} 44^{\prime} 56^{\prime \prime} \mathrm{N} 52^{\circ} 26^{\prime} 28^{\prime \prime} \mathrm{W}$, 75 m, Mont. Chevaux/ Com. Roura, 26.IX.2015/SEAG leg [col.]", "Piège à vitre", "o", 1 ex. [MNHN] (Fig. 1M). PARATYPES: 3 females with labels: "French Guyane, Roura/ Montagne des Chevaux,/

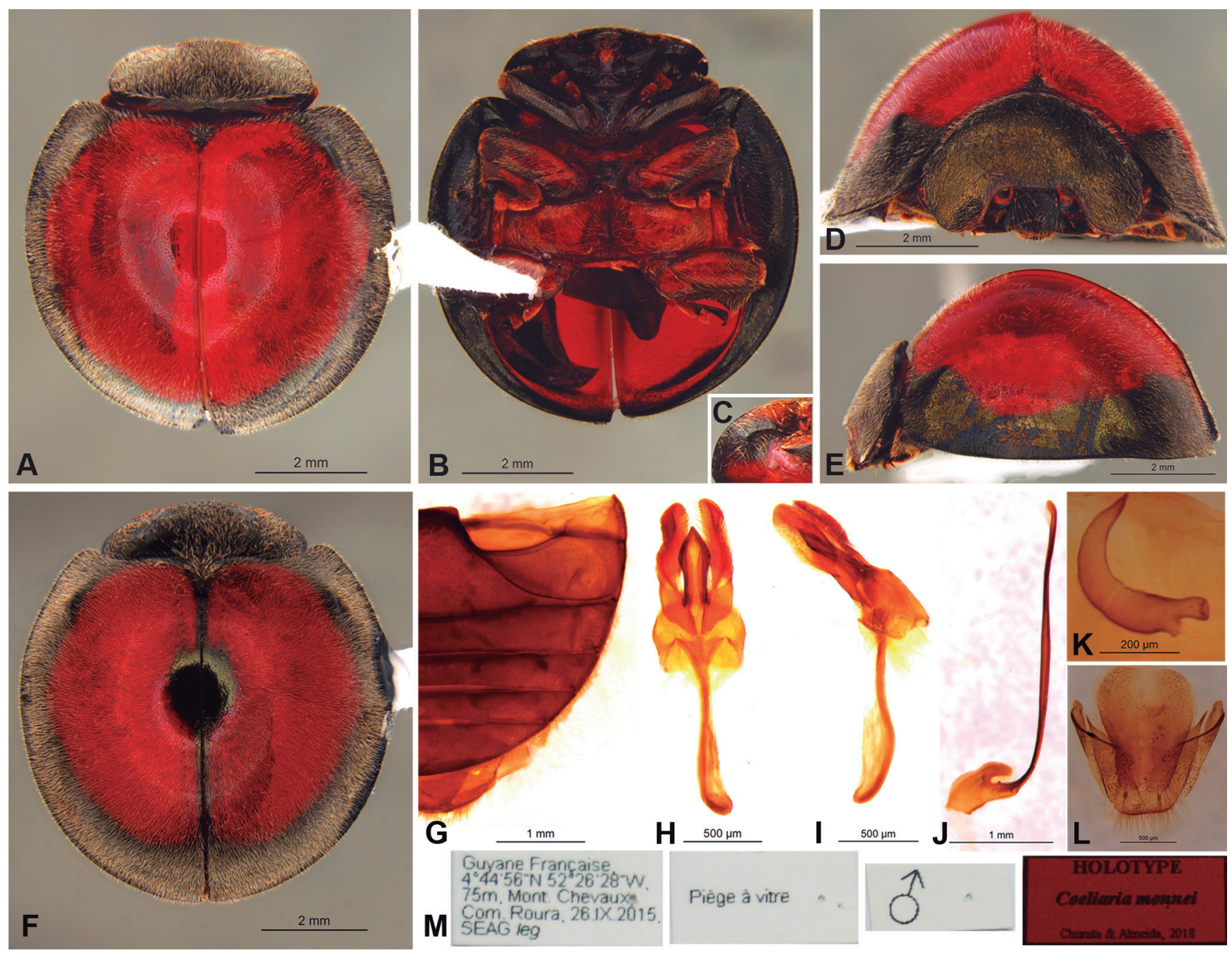

Figure 1. Coeliaria monnei Churata \& Almeida sp. nov. Holotype (A) dorsal view, (B) ventral view, (C) fovea in hypomera, (D) frontal view, (E) lateral view, (F) Paratype showing spot variation, $(\mathrm{G})$ abdomen. Male genitalia: $(\mathrm{H})$ tegmen, ventral view, $(\mathrm{I})$ tegmen, lateral view, $(\mathrm{J})$ penis. Female genitalia: $(\mathrm{K})$ spermatheca, $(\mathrm{L})$ coxites; $(\mathrm{M})$ labels. 
RN2 PK22, vitre/ 14-IV-2010/ Stéphane Brulé leg [col.]", "O", 1 ex. [MNHN]; "Guyane française/ Montagne des Chevaux,/ RN2 PK22, Commune/ de Roura, 28-III-2011,/ vitre,/ Stéphane Brulé leg [col.]", "O+", 1 ex. "DZUP/ 289218” [DZUP]; "Guyane Française/ 0444'56"N 52²6'28"W,/ 75 m, Mont. Chevaux/ Com. Roura, 15.III.2015/ SEAG leg [col.]", “Polyvie bleu”, "O\$”, 1 ex. “DZUP/ 146599” [DZUP].

\section{Key to the species of Coeliaria}

1. Elytra with a single color without spots, with reflections 2

1'. Elytra black with one big red spot on each elytron which not extends at the outer border C. monnei Churata \& Almeida sp. nov.

2. Body black or dark brown, with reflections of different colors .

2. Body black, without reflections, elytra very expanded, 5.67 to $10.0 \mathrm{~mm}$. C. erythrogaster Mulsant, 1850

3. Body longer than wide, black, with bronze or blue reflections, 3.08 to $4.0 \mathrm{~mm}$ C. luteicornis (Mulsant, 1850)

3'. Body as long as wide, black or brown, with reflections of other colors... 4

4. Bluish reflections, body 3.0 to $4.0 \mathrm{~mm}$..C. bernardinensis (Brèthes, 1925)

4. Brown reflections, body $5.0 \mathrm{~mm}$

C. castanea Churata-Salcedo \& Almeida, 2017

\section{ACKNOWLEDGEMENTS}

We thank CAPES for the award of Master's fellowships to JMCS $(1578651 / 2016)$ and CNPq for the research fellowship to LMA (308992/2017-2). This is contribution number 1961 of the Department of Zoology, Universidade Federal do Paraná.

\section{REFERENCES}

Churata-Salcedo, J.M. \& Almeida, L.M. 2017. Review of Coeliaria (Coleoptera: Coccinellidae: Chnoodini). Zoologia, 34: 1-11. D0l

Mulsant, E. 1850. Species des Coléoptères trimères sécuripalpes. Annales des Sciences Physique et Naturelles d'Agriculture et d'Industrie, Série 2, Lyon, 2:1-1104. D0I 